\title{
LEGAL REGULATION OF BIOETHICAL ISSUES IN THE LIGHT OF MEDICAL SCIENCE ACHIEVEMENTS
}

DOI: 10.36740/WLek202012217

\author{
Nataliia M. Akhtyrska, Olena Yu. Kostiuchenko \\ INSTITUTE OF LAW OF TARAS SHEVCHENKO NATIONAL UNIVERSITY OF KYIV, UKRIANE
}

\begin{abstract}
The aim: To identify issues of legal support for the use of genetics' advances in medicine, reproductive technologies, etc. and to identify criteria for admissibility of safe and ethical implementation of scientific results.

Materials and methods: The analysis of international acts, legislation of European countries, scientific reports on the results of achievements in medicine, in particular, the study and modification of DNA. Decisions of the European Court of Human Rights and a sample survey were used. The study is based on a combination of philosophical approaches, theoretical (dialectical, logical, historical, analysis and synthesis), specific legal and sociological methods of scientific knowledge.

Conclusions: It is necessary to adopt at the UN level the Convention on the Control of Genetic Programming, to clearly define international cooperation in the field of prevention and counteraction to experiments on editing the genome of the "best man". Governments should adopt regulations based on certain standards of "preservation of human genetic identity", to establish the order of location of laboratories or other institutions on the territory of the states conducting research with genetic material.
\end{abstract}

KEY WORDS: germ cells, DNA, genome

Wiad Lek. 2020;73(12 p. II):2804-2809

\section{INTRODUCTION}

Today's rapid development of medicine and scientific advances in physiology, genetics, molecular biology, pharmacology makes it possible to effectively treat acquired serious diseases, congenital genetic defects, positively solve the problems of human reproductive functions. At the same time, such studies and application of their results should not be deprived of control, legal regulation, as well as biosafety and ethics. The coronavirus pandemic has clearly demonstrated the need for transparency in the results of scientific laboratories, legitimacy of certain experiments, to protect humanity from the risks of leaking unauthorized and unsuccessful scientific products of scientific experiments, which also leads to negative economic consequences and diplomatic complications. (in particular, the statement of D. Trump "kung fu flu").

It is obvious that science is created and lives in a closed space, in a laboratory, but the subject of its research must be known to society, proven in an accessible form, especially in medicine. Science satisfies the desire of scientist to go beyond the known, but the result is used by society, which decides on the safety and usefulness, limitation or further prohibition of implementation of scientific result. The discovery itself, which is undoubtedly extremely necessary, sometimes arouses suspicion and opposition from citizens, as there were no discussions on the issue, no indication of research subjects, sources of funding, customers. So far, conspiracy theories have emerged about chipping citizens under the guise of vaccination against COVID-19 only on the grounds that Bill Gates joined in funding the search for the vaccine. This is due to the public's ignorance that the Bill and Melinda Gates Foundation is sponsoring medical research not only now, but that such assistance has been provided on an ongoing basis. For example, in 2010, the Foundation's funds were used to implement the idea of transforming DNA-cleaving enzymes into something like a diagnostic tool for detecting human-specific RNA molecules, including Dengue fever and yellow fever.

Public relations, regardless of the field, need legal regulation - from the legality of location of scientific laboratories (including foreign ones), infrastructure (locations considering environmental and other biological risks) and transparency of research to conduct experiments. However, currently such normative acts not adopted at the national or the international levels, legal policy does not correspond to the rapid development of science. This year, the Nobel Prizes in Medicine are awarded (almost every tenth for achievements in the field of immunology - in 2018, James Allison (James Patrick Allison), Tasuku Honjo for discovering the mechanism that inhibits the activity of T-lymphocytes, immune cells-killers of cancer cells, however, the agenda of meetings of international organizations and parliaments of the states are rarely addressed issues of regulation of these issues.

\section{THE AIM}

Identify problematic issues of legal support for the use in medicine of advances in genetics, reproductive technolo- 
gies, etc. and identify criteria for admissibility of safe and ethical implementation of scientific results.

\section{MATERIALS AND METHODS}

The study is based on the analysis of international law on human rights and biomedicine (6 conventions and additional protocols to the conventions was analyzed); legislation of Ukraine; scientific reports on the results of advances in medicine, in particular, on the study and modification of DNA in the United States; judgments of the European Court of Human Rights. The empirical basis of the manuscript was the results of a sample survey conducted in December 2019 - January 2020 by 54 doctors and other health professionals (ranked depending on place of residence, level of clinic, specialization, work experience, degree, etc.). The article uses philosophical approaches to scientific knowledge and a set of methods of scientific research: theoretical (dialectical, logical, historical, analysis and synthesis), specific legal (comparative legal, formal legal), sociological (questionnaire).

\section{REVIEW AND DISCUSSION}

What is the first thing that prevails - medicine or law? Is it possible to combine and harmonize them for the people service? A person has an inalienable natural right to life, the right to health care, and in the event of encroachment, a legal mechanism is activated. Can scientific medical experiments in search of a cure for the disease be harmful to human health? What should be the actions of lawyers to prevent and counteract the negative consequences? What is the scale of regulations - national or international - to protect humanity from biological threats? These issues arise periodically and are addressed in the international legal acts of the World Health Organization, established at the UN in 1946, the World Medical Association, established in 1947, which, in particular, adopted the Declaration of Human Rights and Freedom of Health Workers (1985), Declaration on Euthanasia (1987), Declaration of Helsinki, Recommendation for Physicians Conducting Biomedical Research on Humans (1964), Declaration on Human Organ Transplantation (1987), Statement on Trafficking in Living Organs (1985), etc.

Council of Europe Convention on the Protection of Human Rights and Dignity of the Human Being with regard to Biology and Medicine: The Convention on Human Rights and Biomedicine of 1997 April, 4 was adopted with the recognition that biology and medicine are evolving rapidly, that will threaten human dignity; that progress in biology and medicine must be used for the benefit of present and future generations; that international cooperation is necessary for all mankind to be able to use the achievements of biology and medicine [1].

Directive № 2010/45/EU of the European Parliament and of the Council of Europe on standards of quality and safety of human organs intended for transplantation of 7 July 2010 drew the attention of states to the need for international control over transplantation, as such operations are performed by medical institutions or specialists from different jurisdictions. There are significant differences between varied EU Member States as to their requirements for the quality and safety of transplantation. In view of these facts, there is a need to develop common standards for preparation, transport and use of organs at European Union level. These standards are designed to facilitate the exchange of organs for the benefit of thousands of European patients who need this medical care every year. European Union legislation must ensure that bodies comply with recognized quality and safety standards. These standards should reassure the public that bodies trained in other countries have the same quality and safety guarantees as bodies trained in their own countries.

The practice of organ donation and transplantation, which involves the illegal transportation of organs, is considered unacceptable. In certain cases, this practice involves the illicit transport of persons for the purpose of removing organs, which is a serious violation of inalienable human rights and, in particular, the human right to respect for one's dignity and physical integrity. Although the main objective of this Directive is the safety and quality of organs, it is also directly aimed at the illicit transport of organs. This goal is achieved by creating competent authorities to issue permits for the establishment of organ transplant centers, creating conditions for the training of organs and monitoring systems for this process [2]. This Directive does not address the risk of human organ transplantation, the scope of standards is limited to EU countries, which allows to address these issues in some way (territorially and in time) but does not solve the problem as a whole.

Scientific advances in cell and molecular technology have led to the development of advanced therapies, such as gene therapy, somatic cell therapy and tissue engineering. This new field of biological medicine offers new opportunities for the treatment of diseases and disorders of the human body, the relevant Regulation (EU) N 1394/2007 of the European Parliament and of the Council "On advanced therapy medicinal products" amending Directive 2001/83/ EU and to Regulation (EU) No 726/2004 "This Regulation lays down specific rules concerning the authorization, pharmacovigilance and control of advanced therapy medicinal products [3].

The CIS has adopted a Model Law on the Protection and Dignity of Man in Biomedical Research in the CIS Member States, which applies to all types of biomedical research involving humans, including in vivo embryos, but excluding in vitro embryo research. (Article 2). It is noteworthy that this law draws attention to biomedical research involving vulnerable groups, which include minors, persons with mental disorders, pregnant women and nursing mothers, persons serving sentences in penitentiary institutions, servicemen, migrants, as well as individuals and communities of people who are in different conditions of financial, administrative, national, religious, racial and other dependence. When conducting biomedical research with the participation of a vulnerable contingent, special 
procedures are taken into account, which take into account the factors of age, intellectual, mental or social immaturity of the research participant (Article 24). It should be noted that, in accordance with Art. 28, epidemiological and social studies, combined with minimal risks for study participants or those that do not foresee such consequences, may be conducted without directly informing and obtaining the consent of potential study participants, but subject to independent ethical expertise and with the consent of authorized state body established by law. The principle of confidentiality and liability insurance in accordance with state law must be observed.

As stated in Art. 29, when conducting any biomedical research that involves obtaining information about the genetic data of the research participant, it is necessary: to provide the ethics committee with reliable and convincing data on feasibility of such studies, their usefulness or potential benefits of scientific data for research participants or others; obtain separate informed consent; ensure all necessary confidentiality measures; not to discriminate on the basis of obtaining genetic information; to ensure compliance with the requirements for such a procedure by law, as well as by generally accepted principles and norms of international law [4].

Ukraine has not yet adopted relevant legislation, and it must be acknowledged that the Convention on Human Rights and Biomedicine, which deals with transplantation of organs and tissues of human origin, and the Additional Protocol to the Convention on Human Rights and Biomedicine, which relates to biomedical research, have not yet been ratified, despite the fact that the Ministry of Health of Ukraine on 22.05.2007 the order on preparation for ratification of specified documents was approved.

In order to clarify the problematic issues of legal regulation of bioethical problems, we surveyed 54 doctors and other health professionals. Thus, according to the results of generalization of obtained data, it was found that the vast majority of health professionals are well acquainted with current bioethical problems (93\%), in particular, 29\% indicated the problems of organ and tissue transplantation in humans; $15 \%$ drew attention to the unregulated euthanasia, 19\% -recognition of the embryo as a person from conception; $7 \%$ - the right of the mother (pregnant) to determine the fate of the embryo (without the partner's consent); $13 \%$ focused on surrogacy; $3 \%$ - conducting research on germ cells; $8 \%$ - biological research on DNA, viruses; $3 \%$ - location of biological foreign laboratories on the territory of Ukraine; $3 \%$ - editing the genes of patients for treatment.

For example, the results of the work of Professor Jennifer Anne Doudna (https://doudnalab.org/), who developed the method of genome editing, were known only to doctors who conduct research, and this is 4 people out of 54 respondents. Nevertheless, $84 \%$ of respondents justify the use of genome editing methods for therapeutic purposes, but categorically against gene editing of future children.

At the same time, $97 \%$ of the surveyed doctors opposed the consolidation of euthanasia (religious, social and mor- al-psychological factors) at the legislative level in Ukraine. $43 \%$ believe that it is appropriate at the regulatory level to determine that a pregnant woman has the right to use fertilized cells for childbirth, despite the partner's objections. The analysis of the survey shows that doctors need to raise awareness of the legal regulation of these issues in the European Union, the United States and other countries; Physicians face risks of violating bioethical principles, as there is legal uncertainty at national and international levels of certain issues (research).

Scientists N.P. Dubinin and Yu.G. Shevchenko in 1976 predicted that "... scientific and technological revolution brings humanity to enter the era of... biology" [5]. They pointed to the possibility of the next 20-30 years due to the achievements of genetics to eradicate hunger, overcome infectious diseases, cancer, cardiovascular disease, and organ transplantation will be ensured by the success of immunogenetics. At the same time, scientists have warned against hasty attempts to create a genetically better person, as this will have socially unpredictable consequences. At the same time, they did not deny that over time, the need for biological improvement will inevitably arise before science in connection with qualitatively new living conditions, habitats, which may be caused by cosmic or terrestrial factors.

In 1990, with the support of the US Department of Energy, the United Kingdom, France, Japan, China and Germany, the Human Genome Project was launched under the leadership of Francis Collins, head of the International Human Genome Sequencing Consortium. Scientists set themselves the following tasks: identification of 20-30 thousand DNA genes; establishing the sequence of 3 billion pairs of chemical bases that make up human DNA and storing this information in a database; improvement of devices for data analysis; introduction of the latest technologies in the sphere of private use; research on ethical, legal and social issues that arise during the decoding of the genome To solve the problem it was spent more than $\$ 3$ billion, and in 2001 it was published the result of a scientific search. The process of DNA and genome sequencing later became available, and scientists were able to identify more than 4,000 types of DNA mutations that cause genetic diseases. The results of the research helped scientists to establish links between multiple gene variants and human physical and behavioral traits.

In this regard, Francis Fukuyama noted that the scientific offensive in all these areas has potentially political consequences, because they expand our knowledge of the brain, the source of human behavior, and consequently the ability to control it "[6].

The open method of genome sequencing was exclusively a diagnostic tool, not a method of treatment. The challenge for scientists was to find a way to influence the correction of a defective gene. Scientists have discovered that viruses are able to embed new genetic information in the DNA of bacterial cells. Viruses were used as a vehicle to deliver a given content, as a vector or, in the words of scientists, a "Trojan horse". The so-called gene targeting process was used to correct mutations in the genome. In 2007, Capekki, 
Smithis, and Evans received the Nobel Prize in Physiology or Medicine, in which they succeeded in deriving a live mouse with simulated changes as a result of gene targeting in mouse embryonic cells.

In 2012, the results of the CRISPR study were published, which emphasized the usefulness of a programmable enzyme capable of cleaving DNA for genome editing. As Jennifer Dudna points out, "when you gain power over the code of life, it comes with a certain level of responsibility that we are not ready for. Weighing the risks of technology like CRISPR against the responsibility to use its power to benefit humanity and the planet will be an unprecedented challenge. And still we have to go through it. Given the stakes, we simply have no choice. "[7]

According to scientists, we are on the threshold of a new era in the history of life on Earth - an era when humans have gained an unprecedented level of control over the genetic makeup of species that coexist with them. The use of the open method has a double effect, on the one hand it is aimed at improving treatment methods (use of modified bone marrow of the patient without transplantation), correction of visual impairment in infants, etc., on the other hand uncontrolled use can have negative unpredictable consequences.

The analysis of scientific reports allowed grouping the application of the following methods in the following areas:

1) cultivation of genetically modified plants (slow maturation, adaptation to certain climatic conditions, resistance to natural disasters, protection against insects, etc.);

2) breeding of genetically modified animals (create human diseases in animals for more accurate detection and development of treatment methods - monkeys for autism, pigs for Parkinson's, ferrets for influenza). Researchers are humanizing various pig genes for xenotransplantation - transplantation of organs grown in animals to human recipients. These gene editing technologies are used to create designer animals;

3) restoration of the ecological balance disturbed by human intervention in nature, namely restoration, return to life of extinct animal species through cloning and genetic engineering. It should be noted that scientists recognize that CRISPR technology can be used to destroy (extinct) unwanted species.

Emmanuel Charpentier and Jennifer Dudna were awarded the Nobel Prize in Chemistry in 2020 for the discovery of so-called "genomic surgery". According to J. Dudna, there must be an ethical justification for an outright ban on cell modification, just as she does not believe that states have the right to prohibit parents from using modern genetic technology to give birth to a healthy child, the scientist cites Charles Sabina's justification [8].

Scientists in medicine and biology have asked lawyers and politicians about the legitimacy of the use of advanced methods of gene therapy, in particular, it is a question of which cells can be directed to a new discovery - somatic or germinal? Somatic cells are the general name for all cells of multicellular organisms (heart cells, muscle cells, liver cells, etc.). Germinatives are any cells that can be inherited by future generations. According to scientists, embryo editing is the best way to demonstrate the therapeutic potential of CRISPR technology, by correcting a genetic defect in the embryo at an early stage of development.

According to Art. 1 of the Universal Declaration of the Human Genome and Human Rights, adopted by the United Nations on 11 November 1997, the human genome is the basis for the commonality of all members of the human race, as well as the recognition of their inherent dignity and diversity. The human genome marks the dignity of humanity. Therefore, as stated in the Preamble, Recognizing that scientific research on the human genome and the practical application of its results offer unlimited prospects for improving the person's health and of humanity as a whole, emphasizing that such research must be based on comprehensive respect for dignity, freedoms and human rights, as well as the prohibition of any form of discrimination on the grounds of genetic characteristics [9].

UNESCO now indicates in its documents that, although technologies such as CRISPR should be used to prevent the risk of life-threatening diseases, if such an intervention would affect offspring, it would jeopardize the inalienable, equal dignity of all human beings and restore eugenics, disguised as the realization of desire for a better, improved life [10]. Some scientists are also wary of the use of such methods, in particular, G. Annas warns that editing the human genome can significantly change the very concept of "being human", and this change in the gene pool will have detrimental unpredictable consequences [11].

Medical scientists are debating how to draw the line between the use of new methods for treatment (getting rid of diseases) and the improvement of the human species; lawyers are questioning the mechanism of control over these processes. The threat lies in the emergence of genetic discrimination, which is based on financial ability of families to turn to specialists to form a unique individual at the embryo level.

Professor V.Z. Tarantul, who participated in the Human Genome Project, does not rule out that in the future the courts will consider the results of genetic analysis when passing sentence. V.Z. Tarantul cites a case in which the killer's lawyers in a U.S. court helped his client avoid the death penalty by using the results of a genetic examination, findings of which confirmed the hereditary predisposition to the accused to violence. Given this, there is a threat of the return of eugenics, the science of control and influence on hereditary qualities [12]. In scientific discussions, scientists suggest not to use the term "eugenics", replacing it with the word "derivation" (F. Fukuyama), or "liberal eugenics" (Y. Habermas). Obviously, given this opportunity, states will not force parents to edit the genes of future children, however, the prevailing opinion is that giving such a right to the parents themselves is still appropriate.

In some countries, clinical interventions in human germ cells are prohibited, criminal penalties are provided by law (Austria, Brazil, Canada, Germany, France), and in some countries such restrictions do not exist. Scientists are drawing attention to the quality of regulations, which currently do not correspond to clarity and predictability, 
as legal terminology does not reflect the essence of genetic interventions. Thus, in the European Union, "clinical trials of gene therapy which result in modification of the genetic identity of human germ cells" are prohibited [13]. The interpretation of "genetic identity" is quite broad. In France, actions that "violate the integrity of the human species" are prohibited, as are any "eugenic practices aimed at organizing the selection of people." In Mexico, instructions for dealing with human germ cells are limited to the purpose: all purposes except "eradication of serious diseases or defects or alleviation of disease" are prohibited.

According to the analysis of the case law of the European Court of Human Rights, the issue of the person's right to withdraw their consent to the preservation and use of embryos needs additional regulation [14].

\section{CONCLUSIONS}

Given the available technology to influence the human genome, determine the hereditary qualities of offspring, it is advisable to hold international interdisciplinary conferences with geneticists, biologists, ecologists, lawyers, government officials to understand the opportunities, challenges and threats. Based on professional counseling (to avoid terminological differences), it is necessary to adopt at the UN level Convention on the Control of Genetic Programming to clearly define international cooperation in the field of prevention and counteraction to experiments on editing the genome of "best person". Governments should adopt regulations based on certain standards of "preservation of human genetic identity", establish the order of location in the territory of laboratories or other institutions that conduct research with genetic material; provide criminal liability for collection of genetic material, embryos for unlicensed experiments at the legislative level; establish a regime of transparency of foreign laboratories on the territory of states (bacteriological and other). States that do not ratify international conventions and do not implement the standard of protection against genetic inequality set by the international community should be subject to severe sanctions and require access by international experts to the activities of questionable laboratories.

In Ukraine, public unrest is caused by the uncontrolled distribution of advertisements for the purchase of women's eggs (certain characteristics), surrogacy, significant funds are offered as payment, but advertisements do not meet the requirements of the law (no printing, customer, circulation), no clinic address (only price and phone). And there are fears on the basisof this about conducting informal experiments on human embryos, selling babies for scientific experiments, and so on. In a context of COVID-19 there was a discussion in the media about the legality of the presence of foreign laboratories on Ukraine's territory, where scientists from other countries work on issues unknown to society. Prohibition of genetic and biological research on the territory of some states does not solve the problem and only poses a threat of uncontrollability, which will be a threatening consequence.
In order to accelerate legal international harmonization and settlement by introducing strict control over the editing of germ cells, it is necessary to realize that scientific research does not stop for a moment. Procrastination can create a greater risk. The challenge must be accepted. For, as Herbert Wells noted in The Eating of the Gods, "The old scientist's disappointment was so deep and painful that he closed his eyes with his hands and was afraid to open them so as not to see his fears, which had already come true." [15].

\section{REFERENCES}

1. Convention for the Protection of Human Rights and Dignity of the Human Being with regard to the Application of Biology and Medicine: Convention on Human Rights and Biomedicine. 04.04.1997. Available from: https://rm.coe.int/168007cf98. [reviewed 2020.07.10].

2. Directive 2010/45 / EC of the European Parliament and of the Council on the quality and safety standards of human organs intended for transplantation (Strasbourg, 7 July 2010)]. Available from: https:// ec.europa.eu/health/sites/health/files/blood_tissues_organs/docs/ directive_2010_45_en.pdf [reviewed 2020.07.10].

3. Regulation (EC) No 1394/2007 of the European Parliament and of the Council of 13 November 2007 on advanced therapy medicinal products and amending Directive 2001/83/EC and Regulation (EC) № 726/2004 of 13 November 2007. Available from: https://eur-lex.europa.eu/LexUriServ/LexUriServ. do?uri=0]:L:2007:324:0121:0137:en:PDF [reviewed 2020.07.10].

4. Modelniy zakon o zachite prav I dostoinstva cheloveka v biomedizinskich issledovaniyach v gosudarstvach-chlenach SNG. Prinyat na 26 plenarnom zasedanii Mezparlamentskoj Assambley gosudarstvuchastnikov SNG (postanovlenie № 26-10 ot 18 noyabrya 2005 goda) [Model law on the protection of human rights and dignity in biomedical research in the CIS member states. Adopted at the 26th plenary session of the Interparliamentary Assembly of the CIS Member States (Resolution No. 26-10 of November 18, 2005]. Available from: http:// docs.cntd.ru/document/901972162 [reviewed 2020.07.10] (Ru)

5. Dubinin N.P., Chevchenko Y.G. Nekotorie voprosi biosozialnoj prirodi cheloveka. M.: Nauka, 1976.224-225. [Some questions of the biosocial nature of man]. Moscow: Nauka, 1976. P. 224-225] (Ru)

6. Fukuyama F. Nache postchelovecheskoye buduchee: Posledstviya biotechnologicheskoj revolyucii [Our Posthuman Future: Consequences of the Biotechnological Revolution]. Moskva:000 Izdatelstvo AST :0A0 LYUKS. 2004. 34 p. (Ru)

7. Jennifer A. Doudna, Samuel H. Sternberg. A Crack in Creation. Gene Editing and Unthinkable Power to Control Evolution. Houghton Mifflin Harcourt . Boston-New York. 2017: 135.

8. E.C. Hayden Should You Edit Your Children's Genes? // Nature News, February 23, 2016.

9. Universal Declaration on the Human Genome and Human Rights of 11 November 1997. Available from: http://portal.unesco.org/en/ ev.php-URL_ID=13177\&URL_D0=D0_TOPIC\&URL_SECTION=201. html [reviewed 2020.07.10]

10. United Nations Educational, Scientific and Cultural Organization, "Report of the IBC on Updating Its Reflection on the Human Genome and Human Rights," October 2, 2015. Available from: unesdoc.unesco. org/images/0023/002332/233258E.pdf [reviewed 2020.08.15]

11. G. Annas, "Viewpoint: Scientists Should Not Edit Genomes of Human Embryos". April, 30. 2015. Available from: www.bu.edu/ sph/2015/04/30/scientists-should-not-edit-genomes-of-humanembryos/. [reviewed 2020.08.15] 
12. Tarantul V.Z. Genom cheloveka: enziclopediya, napisannaya chetirmya bukvami. Moskva, 2003. P. 210 [The Human Genome: An Encyclopedia Written in Four Letters] (Ru).

13. Isasi R., Kleiderman E., Knoppers B.M. Editing Policy to Fit the Genome? Science 351 (216): 337-339. doi: 10.1126/science.aad6778

14. Case of Evans v. the United Kingdom. 10.04.2007. Available from: https://hudoc.echr.coe.int/eng\#\{\%22appn0\%22:[\%226339/05\%22], \%22itemid\%22:[\%22001-80046\%22]\} [reviewed 2020.07.10]

15. Uells G.B.Pischa bogov: roman [Food of the Gods: Novel]. K.:Vidavnicha grupa KM-BUKS, 2019.:251 (Ru)

\section{ORCID and contributionship:}

Nataliia Akhtyrska: 0000-0003-3357-7722 A, D, F,

Olena Kostiuchenko: 0000-0002-2243-1173 ${ }^{B, D, E}$

\section{Conflict of interest:}

The Authors declare no conflict of interest.

\section{CORRESPONDING AUTHOR}

Nataliia Akhtyrska

Institute of Law of Taras Shevchenko National University of Kyiv tel: +380442393186

Fax: +380442393237

e-mail: Akhtyrska.n@gmail.com

Received: 28.08 .2020

Accepted: 30.11 .2020

A - Work concept and design, B - Data collection and analysis, C - Responsibility for statistical analysis, D-Writing the article, $\mathbf{E}$-Critical review, $\mathbf{F}$ - Final approval of the article 